DOI: 10.12957/demetra.2016.18071

\title{
Nutritional screening of elderly by different methods and indicators admitted to hospital
}

\section{Avaliação Nutricional de idosos admitidos em uma unidade hospitalar por diferentes métodos e indicadores}

Fernanda Cristina Esteves de Oliveiral Jackline Freitas Brilhante de São Josée Hudsara Aparecida de Almeida Paula ${ }^{3}$ Andréia Queiroz Ribeiro ${ }^{4}$

Carla lamin Gomide ${ }^{5}$

Rita de Cássia Gonçalves Alfenas ${ }^{4}$

1 Universidade Federal de Viçosa, Departamento de Nutrição e Saúde, Programa de Pós-graduação em Ciência e Tecnologia de Alimentos. ViçosaMG, Brasil.

${ }^{2}$ Universidade Federal do Espírito Santo, Departamento de Educação Integrada em Saúde, Centro de Ciências da Saúde. Vitória-ES, Brasil.

${ }^{3}$ Universidade Federal de Alfenas, Departamento de Nutrição. Alfenas-MG, Brasil.

${ }^{4}$ Universidade Federal de Viçosa, Departamento de Nutrição e Saúde. Viçcosa-MG, Brasil.

${ }^{5}$ Hospital São João Batista. Viçosa-MG, Brasil.

Correspondência / Correspondence Fernanda Cristina Esteves de Oliveira Universidade Federal de Viçosa, Departamento de Nutrição e Saúde.

Av. P.H. Rolfs, s/n - 36570-000, Viçosa-MG, Brasil. E-mail: fernandaestevesufv@gmail.com

\begin{abstract}
Objective: Identify appropriate methods and indicators to assess elderly nutritional status admitted to a hospital. Methods: Cross-sectional study in which 41 elderly patients of both sexes were evaluated ( $\geq 60$ years). Body weight, height, body mass index (BMI), brachial circumference (BC), waist circumference (WC), calf circumference (CC), hematocrit, hemoglobin, and total lymphocyte count were evaluated. The Mini Nutritional Assessment (MNA) was also applied. Results: Among 41 elderly evaluated, $53.7 \%$ were female. The classification of the nutritional status obtained through MNA and BMI showed that $80.48 \%$ and $70.73 \%$ of the elderly were diagnosed with inadequate nutritional status, respectively. Strong positive correlation between MNA x BMI, MNA x CC, MNA x BC, BMI x CC and BMI x BC was observed. Kappa analysis showed a moderate agreement only between MNA x BMI and MNA e BC. Conclusion: The results suggest that MNA, BMI and BC were the most suitable methods for nutritional screening of hospitalized elderly.
\end{abstract}

Key words: Elderly. Nutritional Assessment. Body Mass Index. Mini Nutritional Assessment.

\section{Resumo}

Objetivo: Identificar métodos e indicadores apropriados para avaliação nutricional de idosos admitidos em uma unidade hospitalar. Métodos: Tratou-se de estudo transversal, no qual foram avaliados 41 pacientes idosos ( $\geq 60$ anos), de ambos os sexos. Avaliaram-se o peso corporal, altura, índice de massa 
corporal (IMC), circunferência braquial (CB), circunferência da cintura (CC), circunferência da panturrilha (CP), hematócrito, hemoglobina e contagem total de linfócitos. Também se aplicou a Miniavaliação Nutricional (MAN). Resultados: Dos 41 idosos avaliados, 53,7\% eram mulheres. A classificação do estado nutricional obtido por meio da MAN e IMC mostrou que $80,48 \%$ e $70,73 \%$, respectivamente, dos idosos apresentavam estado nutricional inadequado. Observou-se forte correlação positiva entre a MAN x IMC, MAN x CP, MAN x CB, IMC x CP e IMC x CB. Por outro lado, pela análise de Kappa observou-se concordância moderada apenas entre MAN x IMC e MAN e CB. Conclusão: Os resultados sugerem que a MAN, o IMC e a CB foram os métodos mais adequados para a triagem nutricional de idosos hospitalizados.

Palavras-chave: Idosos. Avaliação Nutricional. Índice de Massa Corporal. Miniavaliação Nutricional.

\section{Introduction}

The elderly population has increased all over the world. It is estimated that there will be 1.2 billion people aged 60 years or older in 2020, and about 2.0 billion in $2050 .^{1}$ As we age, there is an increase in the number of hospitalizations. It is also common the occurrence of previous protein-energy malnutrition, which can get worse during hospital stay. The prevalence of malnutrition among the elderly ranges from $1.1 \%$ to $100 \%$, according to the type of variable assessed and the standards used to classify the nutritional status. ${ }^{2}$

This situation has been related to high morbidity rates, which increase the probability of clinical and surgical complications and infections, leading to increased medical care costs and increased mortality rate among elderly. ${ }^{3}$ So it is very important to assess the nutritional profile of this population, using nutritional assessment methods and indicators capable to identify patients with inadequate nutritional status and to establish early intervention measures to minimize health damages. However, a reliable assessment of the nutritional status of the elderly is complex, because during the natural aging process changes occur in anthropometric and biochemical parameters. Therefore, more appropriate evaluation indicators and methods should be used for this group.

There is still no gold standard method to evaluate malnutrition in elderly. Anthropometric measures and biochemical tests (total lymphocyte count, albumin and 
cholesterol, hemoglobin, hematocrit and transferrin) are considered benchmarks for assessing nutritional status of elderly. ${ }^{4}$ However, it is observed that often in clinical practice these methods are not used, due to the elderly physical and financial limitations.

Body Mass Index (BMI), calf circumference (CC) and brachial circumference (BC) are tools used to identify patients presenting nutritional risk and can be used in population studies because they are simple, quick, non-invasive and inexpensive methods. ${ }^{5,6} \mathrm{MNA}$ is a more specific method for the assessment of malnutrition risk in elderly before the clinical changes ocurr. ${ }^{7}$ According to this method, the main factors that represent nutritional risk such as cognitive function, social behavior, autonomy, mobility and anthropometry, are evaluated. ${ }^{8}$

This study aimed to assess the nutritional status of hospitalized elderly patients, using different methods and indicators, in order to identify the most appropriate evaluation criteria for this group.

\section{Material and Methods}

The study was performed in a hospital in Viçosa, Minas Gerais state, Brazil. It was a cross-sectional study, in which 41 male and female elderly patients ( $\geq 60$ years) were evaluated at hospital admission (considering until the second day). The sample represented $51.3 \%$ of the number of elderly hospitalized from October to November in 2007, and most of them were women (53.7\%). Patients with physical disabilities and bedridden were excluded from the study, due to the impossibility of anthropometric assessment. Those who had difficulty answering the MNA and did not have a person responsible who could help them were also excluded.

Anthropometric measurements - weight, height, Body Mass Index (BMI), brachial circumference (BC), waist circumference (WC), calf circumference (CC) - and biochemical tests (hematocrit, hemoglobin and total lymphocyte count) were evaluated. Besides, the subjective method $\mathrm{MNA}^{9}$ was applied by a single trained researcher, to minimize distortions in the final diagnosis.

Weight was measured with the use of a portable scale (Sunrise ${ }^{\circledR}$ ) with $130 \mathrm{~kg}$ capacity. The patients were barefoot, with light clothes, at standing position, with arms outstretched and with the eyes towards the horizon. Height was estimated through length from the heel to the kneecap,,$^{10}$ obtained using an anthropometer with wooden rod, graduated in $0.5 \mathrm{~cm}$ and 1 meter capacity. BMI was calculated dividing weight $(\mathrm{kg})$ by squared height (m). The classification of nutritional status was performed according to Lipschitz. ${ }^{11}$ 
WC, BC and CC were measured using an inelastic tape. WC was measured at the midpoint between the bottom of the last rib and the iliac crest. Measurement was taken at the time of expiration, in the millimeter closest to $0.1 \mathrm{~cm}$. The risk for development of cardiovascular diseases was also assessed according to World Health Organization (WHO). ${ }^{12} \mathrm{BC}$ was measured on the right side of the body, at the midpoint between the lateral projection of acromion process of the scapula and the inferior margin of the olecranon process of the ulna. CC was measured with the patient on supine position, with the left knee raised and the calf at right angle to the bed..$^{13}$ The measurement tape was placed around the calf at the maximal circumference. Subcutaneous tissues were not compressed. The classification of nutritional status by $\mathrm{BC}$ was performed according to Blackburn ${ }^{14}$ with percentile values established by the NHANES III ${ }^{15}$ while for CC, WHO recommendations were used..$^{13}$

It is important to highlight that this study was not funded by any agency. For that reason, biochemical tests were evaluated through data registered on the medical records of the patient. The reference values proposed by Martins et al. ${ }^{16}$ were used to classify the nutritional status through the biochemical tests.

The results were grouped into two classification levels: adequate nutritional status and inadequate nutritional status, in order to facilitate comparison between the methods of nutritional assessment. In the case of BMI, the patients that showed values within the normal weight range $\left(22-27 \mathrm{~kg} / \mathrm{m}^{2}\right)$ were considered with adequate nutritional status, while those who showed values below or above this range were considered with inadequate nutritional status. Since overweight patients cannot be classified with adequate nutritional status and may also show micronutrient deficiencies, which may worsen health conditions during hospital stay, all obese were considered with inadequate nutritional status. For MNA, the malnourished elderly and those at risk of malnutrition were grouped into a single category - inadequate nutritional status. Patients with $\mathrm{CC}<31 \mathrm{~cm}$, and $\mathrm{BC}<$ $90 \%$ adequacy were classified with inadequate nutritional status. Those with $\mathrm{CC}>31$ $\mathrm{cm}$ and $90 \leq \mathrm{BC}$ adequacy $<110$ were classified with adequate nutritional status. Elderly patients with total lymphocyte count, hematocrit and hemoglobin values below the range of $1500-5000 / \mathrm{mm}^{3}, 36-48 \%, 13,5-18 \mathrm{~g} / \mathrm{dl}$ (men); 12-16g/dl (women), respectively, were considered with inadequate nutritional status. Those who showed the values within the recommended range were considered to have adequate nutritional status.

Information about the occurrence of diseases associated to the health of the elderly was also obtained from medical records. Morbidity data were categorized according to the 
nomenclature proposed by the International Classification of Diseases $10^{\text {th }}$ revision (ICD10). Diseases were grouped into classes: diseases of the circulatory system (hypertension); endocrine, nutritional and metabolic diseases (hypothyroidism, diabetes); diseases of the respiratory system (pulmonary disease); diseases of the digestive system (diseases of the gastrointestinal tract); external causes (lesions); other causes (surgery, infections); diseases of the genitourinary system (kidney diseases).

Statistical analysis was carried out with SPSS version 17.0 and Epi info 6.0 software systems. Means, standard deviations, medians, minimum and maximum were used as descriptive statistics. Spearman's correlation coefficients were determined in correlation analysis and were kappa adjusted. Mann-Whitney test was used for statistical comparisons. Chi-square analysis was used to determine the association between nutritional assessment methods. P-values of less than 0.05 were considered statically significant.

This study was approved by the Ethics Committee of the University Federal of Viçosa (029/2007, Viçosa, Minas Gerais, Brazil). The study followed the Helsinki guidelines and all participating subjects gave their written consent.

\section{Results}

The mean age, BMI and WC of the 41 old adults (22 women and 19 men) evaluated were $71.61 \pm 9.70$ years and $25.18 \pm 6,35 \mathrm{~kg} / \mathrm{m}^{2}, 93.31 \pm 11.63 \mathrm{~cm}$, respectively. The most frequent disease types presented by the elderly of this study were: diseases of the circulatory system (63.5\%); endocrine, nutritional and metabolic diseases (34.2\%) and diseases of the digestive system $(24.4 \%)$. The highest incidence of these diseases was observed in the group with inadequate nutritional status ( $\mathrm{p}>0.05), 54.0 \% ; 29.3 \%$ and $19.5 \%$, respectively.

Among the participants, 36.6\% showed BMI $<22 \mathrm{~kg} / \mathrm{m}^{2} ; 29.3 \%$ had BMI ranging from 22 to $27 \mathrm{~kg} / \mathrm{m}^{2}$; and $34.1 \%$ presented BMI $>27 \mathrm{~kg} / \mathrm{m}^{2}$. The values of age, anthropometry, body composition, biochemical tests, BMI and MNA obtained according to the gender of the hospitalized elderly are shown in Table 1. 
Table 1. Mean \pm SD and median (minimum/maximum) age, anthropometric data, body composition, biochemical test, BMI and MNA values obtained according to the gender of the hospitalized elderly, Viçosa-MG, 2007.

Gender

\begin{tabular}{|c|c|c|c|c|c|c|}
\hline \multirow{2}{*}{ Variables } & \multirow{2}{*}{$\begin{array}{c}\text { Total } \\
\text { Mean } \pm \text { SD }\end{array}$} & \multicolumn{2}{|c|}{ Female $(\mathrm{n}=22)$} & \multicolumn{2}{|c|}{ Male $(\mathrm{n}=19)$} & \multirow[b]{2}{*}{$p$} \\
\hline & & Mean \pm SD & $\begin{array}{c}\text { Median } \\
(\min / \max )\end{array}$ & Mean \pm SD & $\begin{array}{c}\text { Median } \\
(\min / \max )\end{array}$ & \\
\hline Age (years) & $71.61 \pm 9.70$ & $\begin{array}{c}73.82 \pm \\
9.80\end{array}$ & $\begin{array}{c}73 \\
(61 / 89)\end{array}$ & $69.05 \pm 9.15$ & $\begin{array}{c}66 \\
(60 / 91)\end{array}$ & 0.117 \\
\hline Weight (kg) & $\begin{array}{c}64.04 \pm \\
15.33\end{array}$ & $\begin{array}{c}59.23 \pm \\
14.17\end{array}$ & $\begin{array}{c}58 \\
(36 / 84)\end{array}$ & $68.84 \pm 16.75$ & $\begin{array}{c}68 \\
(48 / 107)\end{array}$ & 0.053 \\
\hline Height (cm) & $\begin{array}{c}158.89 \pm \\
7.67\end{array}$ & $\begin{array}{c}153.44 \pm \\
7.87^{*}\end{array}$ & $\begin{array}{c}153.73 \\
(139.3 / 170.65)\end{array}$ & $\begin{array}{c}164.35 \pm \\
7.26^{*}\end{array}$ & $\begin{array}{c}164.05 \\
(149.58 / 178.3)\end{array}$ & $0.001 * *$ \\
\hline $\mathrm{WC}(\mathrm{cm})$ & $93.31 \pm 11.63$ & $\begin{array}{c}91.89 \pm \\
12.15\end{array}$ & $\begin{array}{c}91.6 \\
(71 / 119)\end{array}$ & $94.95 \pm 11.09$ & $\begin{array}{c}94 \\
(79.5 / 119.5)\end{array}$ & 0.407 \\
\hline $\mathrm{BC}(\mathrm{cm})$ & $\begin{array}{c}28.18 \pm \\
4.34\end{array}$ & $\begin{array}{c}28.00 \pm \\
4.38\end{array}$ & $\begin{array}{c}27.25 \\
(21.50 / 35.50)\end{array}$ & $28.37 \pm 4.20$ & $\begin{array}{c}27.00 \\
(22.50 / 38.00)\end{array}$ & 0.786 \\
\hline $\mathrm{CC}(\mathrm{cm})$ & $\begin{array}{c}34.30 \pm \\
5.46\end{array}$ & $\begin{array}{c}33.09 \pm \\
4.74\end{array}$ & $\begin{array}{c}32.50 \\
(24.60 / 43.50)\end{array}$ & $35.49 \pm 6.05$ & $\begin{array}{c}34.50 \\
(27.00 / 55.00)\end{array}$ & 0.158 \\
\hline $\begin{array}{l}\text { TLC* (cels/ } \\
\left.\mathrm{mm}^{3}\right)\end{array}$ & $1379.87 \pm 515.12$ & $\begin{array}{c}1232.52 \pm \\
426.26\end{array}$ & $\begin{array}{c}1258 \\
(205 / 2100)\end{array}$ & $\begin{array}{c}1521.63 \pm \\
562.78\end{array}$ & $\begin{array}{c}1564 \\
(396 / 2472)\end{array}$ & 0.073 \\
\hline Hct $(\%)^{*}$ & $\begin{array}{c}36.04 \pm \\
6.81\end{array}$ & $\begin{array}{c}33.45 \pm \\
6.32\end{array}$ & $\begin{array}{c}35.80 \\
(16.60 / 39.90)\end{array}$ & $38.64 \pm 7.10$ & $\begin{array}{c}39.70 \\
(21.30 / 48.00)\end{array}$ & $0.008^{* *}$ \\
\hline $\mathrm{Hb}(\mathrm{g} / \mathrm{dl})^{*}$ & $11.56 \pm 2.33$ & $\begin{array}{c}10.75 \pm \\
2.16\end{array}$ & $\begin{array}{c}11.60 \\
(5.50 / 13.00)\end{array}$ & $12.57 \pm 2.42$ & $\begin{array}{c}12.60 \\
(6.90 / 15.70)\end{array}$ & $0.011^{* * *}$ \\
\hline BMI $\left(\mathrm{kg} / \mathrm{m}^{2}\right)$ & $25.18 \pm 6,35$ & $\begin{array}{c}24.80 \pm \\
6.00\end{array}$ & $\begin{array}{c}23.37 \\
(15.46 / 37.30)\end{array}$ & $25.61 \pm 6.85$ & $\begin{array}{c}23.38 \\
(17.62 / 47.98)\end{array}$ & 0.734 \\
\hline MNA & $19.53 \pm 4.44$ & $\begin{array}{c}18.97 \pm \\
4.28\end{array}$ & $\begin{array}{c}20.00 \\
(13.00 / 26.00)\end{array}$ & $20.10 \pm 4.59$ & $\begin{array}{c}20.00 \\
(11.50 / 28.50)\end{array}$ & 0.421 \\
\hline
\end{tabular}

SD: standard deviation; BMI - body mass index; WC - waist circumference; BC - brachial circumference; CC - calf circumference; TLC: total lymphocyte count; Hct: hematocrit; Hb: hemoglobin. MNA: Mini-Nutritional Assessment; SGA: subjective global assessment; * $\mathrm{n}=(40)$ and $* * \mathrm{p}<0.05$ (Mann-Whitney test). Obs: One patient had no biochemical tests in their medical records. 
Men showed hematocrit and hemoglobin mean values significantly higher, as compared to women. However, the other variables evaluated in the study did not differ according to gender (Table 1). According to WC, $70.7 \%(\mathrm{n}=29)$ of the elderly showed risk for cardiovascular diseases, which according to gender corresponded to $46.3 \%$ $(\mathrm{n}=19)$ of women and $24.4 \%(\mathrm{n}=10)$ of men. The risk for cardiovascular disease was 5.70 times greater for women $(\mathrm{p}=0.04)$. Table 2 shows the percentage of elderly classified with adequate nutritional status and with inadequate nutritional status, according to anthropometric, biochemical and subjective methods by gender. Women showed higher percentages of inadequate nutritional status according to MNA, BMI and TLC. On the other hand, males showed a higher percentage of patients with inadequate nutritional status through the assessment by $\mathrm{BC}$ and MNA.

Table 2. Percentage of elderly classified with adequate nutritional status and inadequate nutritional status, according to the anthropometric and biochemical indicators and the subjective method used for nutritional assessment, by gender. Viçosa-MG, 2007.

\begin{tabular}{ccccccc}
\hline \multirow{2}{*}{ Variables } & \multicolumn{2}{c}{$\begin{array}{c}\text { Total } \\
\%(\mathrm{n})\end{array}$} & \multicolumn{2}{c}{$\begin{array}{c}\text { Female } \\
\%(\mathrm{n})\end{array}$} & \multicolumn{2}{c}{$\begin{array}{c}\text { Male } \\
\text { (n) }\end{array}$} \\
\cline { 2 - 7 } & ANS & INS & ANS & INS & ANS & INS \\
\hline BC $(\mathrm{cm})$ & 33.61 & 65.39 & $40.91(9)$ & $59.09(13)$ & $26.32(5)$ & $73.68(14)$ \\
CC $(\mathrm{cm})$ & 71.65 & 32.85 & $59.10(13)$ & $49.90(9)$ & $84.21(16)$ & $15.79(3)$ \\
TLC* (cels/mm $\left.\mathrm{mm}^{3}\right)$ & 37.61 & 2.39 & $22.72(5)$ & $77.28(16)$ & $52.63(10)$ & $47.37(9)$ \\
Hct $(\%)^{*}$ & 50.95 & 9.05 & $54.54(12)$ & $45.46(9)$ & $47.37(9)$ & $52.63(10)$ \\
$\mathrm{Hb}(\mathrm{g} / \mathrm{dl})^{*}$ & 36.60 & 63.40 & $36.36(8)$ & $63.64(13)$ & $36.84(7)$ & $63.16(12)$ \\
$\mathrm{MNA}$ & 19.62 & 0.38 & $18.18(4)$ & $81.82(18)$ & $21.05(4)$ & $78.95(15)$ \\
$\mathrm{BMI}\left(\mathrm{kg} / \mathrm{m}^{2}\right)$ & 29.43 & 0.57 & $27.27(6)$ & $72.73(16)$ & $31.58(6)$ & $68.42(13)$ \\
\hline
\end{tabular}

BMI: body mass index; BC: brachial circumference; CC: calf circumference; TLC: total lymphocyte count; Hct: hematocrit; Hb: hemoglobin. MNA: Mini-Nutritional Assessment SGA: Subjective Global Assessment; ANS: adequate nutritional status; INS: inadequate nutritional status. * $\mathrm{n}=(40)$.

Comparing the classification of the nutritional status obtained by MNA and BMI, it was observed that $80.48 \%$ and $70.73 \%$ of the elderly were classified with inadequate nutritional status, respectively (Table 2). The results indicate that MNA and BMI were able to identify a large percentage of patients with inadequate nutritional status, demonstrating a higher sensitivity to identify inadequate nutritional status of the elderly. 
It was verified a strong positive correlation between the score of MNA and BMI $(\mathrm{r}=0.69$; $\mathrm{p}<0.0001)$; MNA and CC $(\mathrm{r}=0.73 ; \mathrm{p}<0.0001)$; MNA and $\mathrm{BC}(\mathrm{r}=0.90 ; \mathrm{p}<0.0001)$; BMI and CC $(\mathrm{r}=0.85 ; \mathrm{p}<0.0001)$; BMI and BC $(\mathrm{r}=0.90 ; \mathrm{p}<0.0001)$. On the other hand, according to Kappa analysis there was a moderate agreement only between MNA x BMI (kappa $=0,41$; CI95\% $=-0,03$ $0,58)$ e MNA and BC (kappa $=0,41$; CI95\%=-0,03-0,58).

\section{Discussion}

Hospitalized elderly usually have a higher risk of malnutrition, ${ }^{3}$ indicating the need for early nutritional assessment in this group. Therefore, the use of a tool capable of quickly identify patients with inadequate nutritional status is very important. It has been shown that low body weight increases morbidity-mortality risk, reduces functional independence and quality of life, besides extending the patient's stay in hospital and increase costs of health care. ${ }^{3}$

Age did not differ between genders; however, it is noteworthy that the average age found (71.61 \pm 9.70 years) should be considered (Table 1 ) in the nutritional assessment of the study patients. Literature reports higher death rate in individuals aged 70 or more, regardless of gender, with the highest proportion in hospitalized elderly when compared to those living in households and institutionalized ones. ${ }^{17,18}$

No significant difference was observed for mean BMI between genders, however higher percentages of inadequate nutritional status were observed in the elderly $(72.7 \%$ of the women and $68.4 \%$ of the men) (Table 1). Nascimento et al. ${ }^{19}$ found a significant difference between the genders, and a higher prevalence of underweight among elderly males (18.2\%) than women in the same age group (9\%). Furthermore, higher prevalence of overweight was observed among women $(54.5 \%)$ compared to men $(29.6 \%)$. It is noteworthy that in the latter study, ${ }^{19}$ the elderly were not in a hospital as in our study, and the sample size was different, which may partly explain the difference between the results.

Although BMI is an important method for the classification of nutritional status, it does not reflect the regional distribution of body fat or changes in body fat distribution that occurs with aging. The identification of the type of body fat distribution is important, since the accumulation of fat in the abdominal region is closely related to metabolic changes, which may favor the occurrence of cardiovascular diseases and diabetes mellitus. ${ }^{4}$

Currently one of the most commonly used anthropometric indicators for abdominal obesity is waist circumference, and their values can be associated with the risk of developing cardiovascular diseases. Considering all patients evaluated, $70.3 \%$ showed risk for the development of cardiovascular diseases. This risk was significantly higher $(p=0.04)$ 
for women $(n=19)$ compared to men $(n=10)$. Similar result was observed by Santos \& Sichier $\mathrm{i}^{20}$ when body fat distribution in women of different age groups was evaluated by computed tomography. The authors observed that aging promotes physiological changes that affect abdominal adiposity, mainly in females. After menopause, the reduced estrogen levels and increased androgenic activity leads to the redistribution of body fat, with higher concentration in the abdominal region, and lower in the gluteal-femoral region. This body fat redistribution is associated with the increased visceral adipose tissue and reduced subcutaneous adipose tissue in the central region of the body, which increases the risk of cardiovascular disease. ${ }^{20}$

$\mathrm{BC}$ is another method for nutritional status assessment of elderly, which can be used in substitution to BMI or be used as an additional measure, due to its good correlation with BMI. ${ }^{20}$ This method was able to predict inadequate nutritional status in $59.09 \%$ of the women and $73.68 \%$ of the men $(p>0.05)$ (Table 1). Similar result was verified by Menezes \& Marucci, ${ }^{21}$ in which the BC measurement showed high ability to identify older men with inadequate nutritional status. This result may be related to the higher content of subcutaneous fat in women, which represents an important source of energy for them, contributing to greater BC.

$\mathrm{CC}$ has been indicated as a more sensitive indicator of fat free mass loss in elderly. ${ }^{22}$ Tsai et al. ${ }^{23}$ evaluated 497 elderly from Taiwan through different methods. Two of these methods were the original MNA and its simplified version, in which BMI was replaced by CC to verify if this measurement could be an acceptable alternative for those who do not know their current weight. In this study, $18.5 \%$ of the subjects aged 65 years or older did not know their current weight or if there had been any change in previous months. The authors verified that the use of the simplified MNA (with CC) allowed the identification of $93 \%$ of elderly under nutritional risk, while in the original version, only $68.6 \%$ were classified as such. Therefore, it was suggested that CC may be an alternative method to replace BMI in MNA.

There was no significant difference in classification of nutritional status by CC between the genders (Table 1). Lower percentages of inadequate nutritional status $(49.90 \%$ for the women and $15.79 \%$ for the men) were showed by this method compared to BC.

According to the total lymphocyte count (TLC), $62.5 \%$ of the elderly showed inadequate nutritional status. This value was higher than the one observed (26.8\%) in another study which involved the participation of 46 non-hospitalized elderly, assisted by a municipal program for elderly care. ${ }^{24}$ This result is likely due to the fact that our participants were hospitalized elderly, favoring an inadequate nutritional status (malnutrition). However, Kuzuya et al. ${ }^{7}$ observed that TLC was not an appropriate indicator to assess malnutrition 
in elderly, since this variable was not correlated with anthropometric measurements, biochemical markers or MNA. However, it must be noted that the participants of this study presented co-morbidities that could have affected the result.

The TLC has been considered a useful indicator for nutritional status assessment. Its values are progressively reduced as the nutritional status worsens, correlating with morbi-mortality in hospitalized patients. ${ }^{25}$ However, despite being an easily achieved indicator of nutritional status, there are still few evidences that its low concentrations reflect malnutrition in elderly.

Erythrogram components evaluated in this study indicated that $47.5 \%$ of the elderly were considered inadequate nutritional status by their hematocrit, and $62.5 \%$ by hemoglobin values showed. Similar result was observed in a study involving hospitalized elderly with decompensate heart failure, also using hemoglobin value ${ }^{26}$ as an assessment parameter. However, lower values, $30.4 \%$ for hematocrit and $32.6 \%$ for hemoglobin, were observed in another study, ${ }^{24}$ which can be explained by the fact that these patients participated in a municipal program for elderly care and received ambulatory assistance and home care.

The interpretation of these variables requires attention, and although they are able to identify nutrition problems in early stages, the values obtained for these biochemical tests may be influenced by the presence of diseases, stress and use of drugs, which are conditions usually observed in hospitalized elderly. ${ }^{4}$ The result observed showed a worse nutritional and immunological status in elderly women and subclinical deficiencies in this group. However, it must be emphasized that the interpretation of the biochemical tests should be done in association with the anthropometric and clinical data of patients. This form of assessment provides a more accurate diagnosis and permits to perform of early nutrition interventions to prevent energy-protein malnutrition.

The MNA presents $96 \%$ of sensitivity and $98 \%$ of specificity for malnutrition identification. ${ }^{27} \mathrm{MNA}$ is a useful tool, since it is able to detect malnutrition risk in elderly people, allowing the adoption of a quick intervention to prevent further worsening of their health condition, even before the occurrence of clinical and anthropometric changes (WC, BC, CC). Its use in nutritional status assessment of elderly is recommended by both the European Society of Parenteral and Enteral Nutrition, and the French programme National Nutrition Sant. ${ }^{27,28}$

In this study, $80.48 \%$ of the elderly evaluated were diagnosed with inadequate nutritional status by the MNA (Table 2). This result was higher than the observed by Kuzuya et al..$^{29}(77.9 \%)$ among Japanese elderly when underweight and overweight were grouped as inadequate nutritional status for comparison. However, it was lower than the 
percentage verified by Izaola et al. ${ }^{30}(97.8 \%)$ in cancer patients, who are a group under higher malnutrition risk. Panissa \& Vanisson observed that 21 of the individuals (41\%) presented malnutrition. ${ }^{31}$

It was verified a strong positive correlation between the score of MNA and BMI, MNA and CC; MNA and BC; BMI and CC; BMI and BC. Soini et al. ${ }^{32}$ observed strong correlation between the MNA score and the anthropometric variables (BMI and CC). Bonnefoy et al. ${ }^{6}$ observed better correlations between CC and BMI ( $r=0.706$ and $\left.\mathrm{p}<0.001\right)$, CC and albumin $(r=0.219$ and $\mathrm{p}<0.001)$ in 911 hospitalized elderly. Langkamp-Henken ${ }^{33}$ found positive correlation between the scores of MNA and BMI, CC, hemoglobin and hematocrit.

On the other hand, by using kappa analysis there was a moderate agreement only between MNA x BMI, (kappa $=0.41$; CI95\% $=-0.03-0.58)$ and MNA x CB (kappa $=0.41$; CI95\%=-0.03-0.58). This is probably due to the fact that the correlation coefficient is a type of analysis that shows associations between variables, which is sensitive to the magnitude and the variability between individuals, and may overestimate the association.

It must be highlighted that the variation in the values obtained in the studies can be attributed to differences in the population studied: institutionalized, hospitalized or not, ethnical differences, occurrence of diseases, type of pharmacological treatment used, hospital stay duration, and sample size of the study. Another aspect concerns the difference in the forms of nutritional status classification reported in the scientific papers, which makes it difficult to compare the results obtained among the studies.

In addition, it must be pointed out that it was observed higher occurrence of diseases, although non-significant ( $p>0.05$ ), in the group of patients classified with inadequate nutritional status. This result indicates the clinical relevance of performing an early health screening of the elderly patients, since low weight may favor increased susceptibility to infections and morbidity in elderly population. On the other hand, the occurrence of overweight may be related to higher risk of cardiovascular diseases, mainly in association with higher prevalence of metabolic, hormonal, inflammatory and hemodynamic disorders.

However, the main limitation of this study is the sample size, which may not have been sufficient to demonstrate statistical differences between the methods used to assess nutritional status of patients. So further studies should be conducted to confirm or refute these results.

In addition, patients of which were excluded because of a physical disability, bedridden and those who had difficulty answering the MNA and did not have a responsible person who could help them should be considered in further studies on nutritional assessment. The use methods and indicators more appropriate to this group is suggested, since these patients may show even more precarious nutritional status that needs to be taken into account at hospital admission. 


\section{Conclusion}

The results suggest that MNA, BMI and CB were the most suitable methods for nutritional screening of elderly hospitalized patients. Despite the strong correlation between most methods, there was only a weak to moderate agreement between them.

It should be mentioned that although there are several tools for nutritional assessment, none of them is completely satisfactory, which demands the use of several of these tools for an appropriate evaluation. Therefore, further studies should be conducted to establish methods for assessing nutritional status, favoring a reduction in morbidity and mortality and the cost of geriatric medical care, and also contributing the rapid recovery of patients, reducing their stay in the hospital.

\section{Acknowledgments}

We greatly appreciate the collaboration of the patients and commitment of the health professionals from Hospital São João Batista, Minas Gerais, Brazil, to this study.

\section{References}

1. World Health Organization. Ageing and life course [Internet]. Washington DC: The Department of Ageing and Life Course (ALC). 2010. [acesso em: 21 nov. 2010]. Disponível em: http://www.who. int/ageing/about/en/

2. Ruiz-López MD, Artacho R, Oliva P, Moreno-Torres R, Bolamos J, Teresa C, et al. Nutritional risk in institutionalized older women determined by the mini nutritional assessment test: what are the main factors? Nutrition 2003; 19(9):767-71.

3. Vanderwee K, Clays E, Bocquaert I, Gobert M, Folens B, Defloor T. Malnutrition and associated factors in elderly patients: a Belgium cross-sectional, multi-centre study. Clin. Nutr. 2010; 29(4):469-476.

4. Sampaio LR. Avaliação nutricional e envelhecimento. Rev. Nutr. 2004; 17(4):507-514.

5. Sampaio LR; Figueiredo VC. Correlação entre o índice de massa corporal e os indicadores antropométricos de distribuição de gordura corporal em adultos e idosos. Rev. Nutr. 2005; 18(1):53-61.

6. Bonnefoy M, Jauffret M, Kostka T, Jusot JF. Usefulness of calf circumference measurement in assessing the nutritional state of hospitalized elderly people. Gerontology 2002; 48(3):162-69.

7. Kuzuya M, Kanda S, Koike T, Suzuki Y, Iguchi A. Lack of de correlation between total lymphocyte count and nutritional status in the elderly. Clin. Nutr. 2005; 24(3):427-32.

8. Cordeiro RG, Moreira EAM. Avaliação nutricional subjetiva global do idoso hospitalizado. Rev. Bras. Nutr. Clin. 2003; 18(3):106-112. 
9. Guigóz Y, Vellas B, Garry PJ. Assessing the nutritional status of the elderly: the mini nutritional assessement as part of the geriatric evaluation. Nutr. Rev. 1996; 54(1 Pt 2):S59-S65.

10. Chumlea WC, Roche, AF, Steinbaugh, ML. Estimating stature from knee height for persons 60 to 90 years of age. J. Am. Geria. Soc. 1985; 33(2):116-20.

11. Lipschitz DA. Screening for nutritional status in the elderly. Primary Care 1994; 21(1):55-67.

12. World Health Organization. Obesity: preventing and managing the global epidemic. Geneva: WHO; 1998. (Technical report series, 894).

13. World Health Organization. Physical status: the use and interpretation of antropometry. Geneva: WHO; 1995. (Technical report series, 854).

14. Blackburn GL, Thornton PA. Nutritional assessment of the hospitalized patients. Med. Cli. North Am. 1979; 63(5):11103-15.

15. Centers for Disease Control and Prevention. Anthropometric reference data for children and adults: United States, 1988-1994. Washington, DC: CDC; 2009. Vital and health statistics. Series 11; n. 249.

16. Martins IS; Marinho SP. O potencial diagnóstico dos indicadores da obesidade centralizada. Rev. Saúde Pública 2003; 37(6):760-67.

17. Otero UB, Rozenfeld S, Gadelha AM, Carvalho MS. Malnutrition mortality in the elderly, southeast Brazil, 1980 - 1997. Rev. Saúde Pública 2002; 36(2):141-148.

18. Sousa VMC, Guariento ME. Avaliação do idoso desnutrido. Rev. Bras. Clin. Med. 2009; 7:46-49.

19. Nascimento CM, Ribeiro AQ, Cotta RMM, Acurcio FA, Peixoto SV, Priore SE, et al. Estado nutricional e fatores associados em idosos do Município de Viçosa, Minas Gerais, Brasil. Cad. Saúde Pública 2011; 27(12):2409-18.

20. Santos DM, Sichieri R. Índice de massa corporal e indicadores antropométricos de adiposidade em idosos. Rev. Saúde Pública 2005; 39(2):163-68.

21. Menezes TN, Marucci MFN. Antropometria de idosos residentes em instituições geriátricas, Fortaleza, CE. Rev. Saúde Pública 2005; 39(2):169-175.

22. Acunã K, Cruz T. Avaliação do estado nutricional de adultos e idosos e situação nutricional da população brasileira. Arq. Bras. Endocrinol. Metab. 2004; 48(3):345-361.

23. Tsai AC, Chang T-L, Wang Y-C, Liao C-Y. Population-specific short-form mini nutritional assessment with body mass index or calf circumference can predict risk of malnutrition in community-living or institutionalized elderly people in Taiwan. J. Am. Diet Asso. 2010; 110(9):1328-1334.

24. Alça LRD, Tibério D, Santos MTBR. Estudo dos componentes do hemograma em pacientes geriátricos. Pesq. Bras. Odontoped. Clin. Integr. 2005; 5(3):261-66.

25. Seiler WO. Clinical pictures of malnutrition in ill elderly subjects. Nutrition 2001; 17(6):496-498.

26. Sales ALF, Villacorta H, Reis L, Mesquita ET. Anemia como fator prognóstico em uma população hospitalizada por insuficiência cardíaca descompensada. Arq. Bras. Cardiol. 2005; 84(3):237-40. 
27. Guigoz Y, Vellas B. Mini Avaliação Nutricional (MAN) na classificação do estado nutricional do paciente idoso: apresentação, história e validação da MAN. In: Vellas B, Garry PJ, Guigoz Y. Mini Nutritional Assessment (MNA): research and practice in the elderly. Vevey: Nestec; 1999. Nestlé Nutrition Workshop Series Clinical \& Performance Programme; 1998; 1:1-12.

28. Vellas B, Guigoz Y, Garry PJ, Nourhashemi F, Bennahum D, Lauque S, et al. The Mini Nutritional Assessment (MAN) and its use in grading the nutritional state of elderly patients. Nutrition 1999; 15(2):116-22.

29. Kuzuya M, Kanda S, Koike T, Suzuki Y, Satake S, Iguchi A. Evaluation of mini-nutritional for japonese frail elderly. Nutrition 2005; 21(4):498-503.

30. Izaola O, De Luis Román DA, Cabezas G, Rojo S, Cuellar L, Terroba MC, et al. Mini Nutritional Assessment (MNA) como método de evaluación nutricional en pacientes hospitalizados. Anales de Medicina Interna 2005; 22(7):313-16.

31. Panissa CO, Vassimon HS. Risco de desnutrição de idosos hospitalizados: avaliando ingestão alimentar e antropometria. DEMETRA: Nutrição e Saúde. 2012; 7(1):13-22.

32. Soini H, Routasalo P, Lagstrom. Characteristics of the mini-nutritional assessment in elderly homecare patients. Eur. J. Clin. Nutr. 2004; 58(1):64-70.

33. Langkamp-Henken B, Hudgens J, Stechmiller JK, Herrlinger-Garcia KA. Mini nutritional assessment an screening scores are associated with nutritional indicators in elderly people with pressure ulcers. J. Am. Diet Assoc. 2005; 105(10):1590-1596.

Recebido: 07/8/2015

Revisado: $21 / 1 / 2016$

Aceito: $14 / 2 / 2016$ 